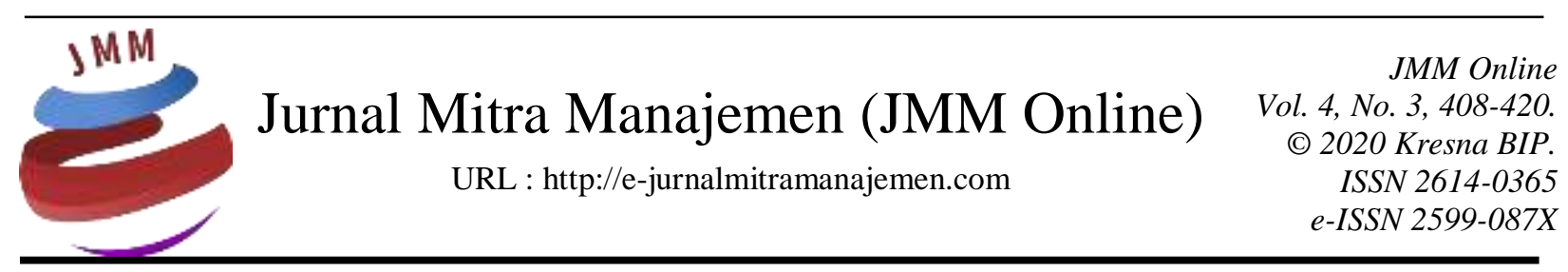

\title{
PENGARUH BUDAYA ORGANISASI, KEMAMPUAN KERJA DAN KOMITMEN ORGANISASI TERHADAP ORGANIZATIONAL CITIZENSHIP BEHAVIOR (OCB) PEGAWAI BAPPEDA KABUPATEN BOJONEGORO
}

\author{
Ahmad Fuad ${ }^{1)}$, Woro Utari ${ }^{2)}$, Nugroho Mardi W. ${ }^{3)}$ \\ Pascasarjana Universitas Wijaya Putra Surabaya
}

\section{INFORMASI ARTIKEL}

Dikirim : 11 Maret 2020

Revisi pertama : 26 Maret 2020

Diterima : 27 Maret 2020

Tersedia online : 30 Maret 2020

Kata Kunci: Budaya Organisasi, Kemampuan Kerja, Komitmen

Email : ahmadfuad173@gmail.com
ABSTRAK

Organizational citizenship behavior (OCB) dibutuhkan oleh suatu organisasi. Terutama pada dunia kerja yang dinamis dimana tingkat fleksibilitas menjadi sangat kritis. OCB adalah peran pegawai diluar job deskripsinya sehingga mendukung keefektifan kegiatan organisasi (Rose dan Liu, 2015). Penelitian ini bertujuan untuk mengetahui deskripsi variabel budaya organisasi, kemampuan kerja, komitmen organisasi, dan organizational citizenship behavior, mengetahui pengaruh budaya organisasi, kemampuan kerja dan komitmen organisasi terhadap organizational citizenship behavior, mengetahui pengaruh budaya organisasi terhadap organizational citizenship behavior, mengetahui pengaruh kemampuan kerja terhadap organizational citizenship behavior, dan mengetahui pengaruh komitmen organisasi terhadap organizational citizenship behavior di Bappeda Kabupaten Bojonegoro.

Berdasarkan hasil analisis data dan pembahasan, maka dapat ditarik kesimpulan bahwa Budaya Organisasi, Kemampuan Kerja, Komitmen Organisasi dan Organizational Citizenship Behavior di Bappeda Kabupaten Bojonegoro semuanya dalam kondisi baik. Budaya Organisasi, Kemampuan Kerja, dan Komitmen Organisasi secara simultan memiliki pengaruh yang signifikan terhadap Organizational Citizenship Behavior di Bappeda Kabupaten Bojonegoro. Budaya Organisasi memiliki pengaruh yang signifikan terhadap Organizational Citizenship Behavior di Bappeda Kabupaten Bojonegoro. Kemampuan Kerja memiliki pengaruh yang signifikan terhadap Organizational Citizenship Behavior di Bappeda Kabupaten Bojonegoro. Serta Komitmen Organisasi memiliki pengaruh yang signifikan terhadap Organizational Citizenship Behavior di Bappeda Kabupaten Bojonegoro. 


\section{PENDAHULUAN}

\section{Latar Belakang}

Suatu organisasi yang sukses membutuhkan pegawai yang akan melakukan pekerjaan melebihi tugas yang biasa mereka kerjakan atau dengan kata lain pegawai tersebut akan memberikan organizational citizenship behavior (OCB) yang melebihi apa yang diharapkan oleh organisasi. Wujud dari perilaku tersebut antara lain: membantu rekan dalam timnya, secara sukarela atau tanpa paksaan melakukan pekerjaan ekstra, mengindari konflik yang tidak perlu diperdebatkan, memberikan support atau budaya organisasi kepada rekan lain apabila mengalami kesulitan dan sesekali mentolerir pekerjaan yang dapat menjadi beban, gangguan dan menyusahkan. Organisasi menginginkan dan membutuhkan pegawai yang akan melakukan hal-hal yang tidak ada dalam diskripsi tugas pekerjaannya.

Pada Bappeda Kabupaten Bojonegoro, OCB ditunjukkan dengan adanya perilaku pegawai yang merasa memiliki organisasi. Sebagai contoh ada staf yang bekerja pada sub bidang sumber daya alam dan lingkungan hidup, pada saat tidak ada kegiatan yang rutin, staf tersebut tanpa diperintahkan langsung membantu sub bidang pekerjaan umum dan perhubungan yang membutuhkan bantuan.

Budaya yang terbentuk di Bappeda Kabupaten Bojonegoro tertanam melalui teladan dan perhatian yang diberikan oleh pegawai dengan jabatan yang lebih tinggi ke pegawai dengan jabatan dibawahnya secara kekeluargaan. Bappeda Kabupaten Bojonegoro memiliki nilai organisasi yang tersalurkan dengan baik kepada pegawai. Selain itu nilai organisasi juga disalurkan melalui kegiatan-kegiatan organisasi seperti briefing baik oleh kepala badan atau kepala bidang yang diadakan tiap minggu, kegiatan gathering tiap hari jumat, dan rapat. Nilai tersebut meliputi tanggung jawab, integritas, dapat menyesuaikan diri dengan lingkungan dan situasi pekerjaan, perlakukan yang adil, dan keramahan. Komitmen yang tinggi menjadikan individu peduli dengan nasib organisasi dan berusaha menjadikan organisasi ke arah yang lebih baik, sehingga dengan adanya komitmen yang tinggi kemungkinan terjadinya kesenjangan anggaran dapat dihindari. Sebaliknya, individu dengan komitmen rendah akan mementingkan dirinya atau kelompoknya. Dia tidak memiliki keinginan untuk menjadikan organisasi ke arah yang lebih baik. (Sumarni, 2010)

\section{Rumusan Masalah}

Berdasarkan latar belakang diatas maka rumusan masalah sebagai berikut:

1. Bagaimana deskripsi variabel budaya organisasi, kemampuan kerja, komitmen organisasi, dan organizational citizenship behavior di Bappeda Kabupaten Bojonegoro?

2. Apakah budaya organisasi, kemampuan kerja dan komitmen organisasi memiliki pengaruh terhadap organizational citizenship behavior di Bappeda Kabupaten Bojonegoro?

3. Apakah budaya organisasi memiliki pengaruh terhadap organizational citizenship behavior di Bappeda Kabupaten Bojonegoro?

4. Apakah kemampuan kerja memiliki pengaruh terhadap organizational citizenship behavior di Bappeda Kabupaten Bojonegoro? 
5. Apakah komitmen organisasi memiliki pengaruh terhadap organizational citizenship behavior di Bappeda Kabupaten Bojonegoro?

\section{Tujuan Penelitian}

Berdasarkan rumusan masalah tersebut maka tujuan dalam penelitian ini adalah sebagai berikut :

1. Untuk mengetahui deskripsi variabel budaya organisasi, kemampuan kerja, komitmen organisasi, dan organizational citizenship behavior di Bappeda Kabupaten Bojonegoro.

2. Untuk mengetahui pengaruh budaya organisasi, kemampuan kerja dan komitmen organisasi terhadap organizational citizenship behavior di Bappeda Kabupaten Bojonegoro.

3. Untuk mengetahui pengaruh budaya organisasi terhadap organizational citizenship behavior di Bappeda Kabupaten Bojonegoro.

4. Untuk mengetahui pengaruh kemampuan kerja terhadap organizational citizenship behavior di Bappeda Kabupaten Bojonegoro.

5. Untuk mengetahui pengaruh komitmen organisasi terhadap organizational citizenship behavior di Bappeda Kabupaten Bojonegoro.

\section{KAJIAN PUSTAKA \\ Organizational Citizenship Behavior}

Pengertian organizational citizenship behavior (OCB) pertama kali di populerkan oleh Organ kemudian dikembangkan oleh tokoh-tokoh lain. OCB dapat didefinisikan sebagai suatu perilaku kerja karyawan di dalam organisasi, yang dilakukan atas suka rela di luar deskripsi kerja yang telah ditetapkan, dengan tujuan untuk meningkatkan kemajuan kinerja organisasi. OCB merupakan perilaku individual yang bersifat bebas (discretionary), yang tidak secara langsung dan eksplisit mendapat pengharapan dari sistem imbalan formal, dan yang secara keseluruhan mendorong keefektifan fungsi-fungsi organisasi. Bersifat bebas dan sukarela, karena perilaku tersebut tidak diharuskan oleh persyaratan peran atau deskripsi jabatan yang secara jelas dituntut berdasarkan kontrak dengan organisasi; melainkan sebagai pilihan personal (Podsakoff, MacKenzie, Paine, \& Bachrach, 2010).

OCB melibatkan beberapa perilaku, meliputi perilaku menolong orang lain, menjadi volunteer untuk tugastugas ekstra, patuh terhadap aturan-aturan dan prosedurprosedur di tempat kerja. Perilaku-perilaku ini menggambarkan nilai tambah karyawan dan merupakan salah satu bentuk perilaku prososial, yaitu perilaku sosial yang positif, konstruktif dan bermakna membantu (Novliadi, 2010).

OCB sebagai perilaku yang merupakan pilihan dan inisiatif individual, tidak berkaitan dengan sistem reward formal organisasi tetapi secara agregat meningkatkan efektivitas organisasi. Hal ini berarti perilaku tersebut tidak termasuk ke dalam persyaratan kerja atau deskripsi kerja karyawan sehingga jika tidak ditampilkan pun tidak diberikan hukuman (Organ, podsakoff, \& macKenzie, 2010).

Menurut Organ; Podsakoff; dan Mackenzie (2010) terdapat 7 (tujuh) indikator dalam organizational citizenship behavior, yaitu : altruism, courtesy, peacemaking, cheerleading, conscientiousness, sportsmanship dan civic virtue. 


\section{Budaya Organisasi}

Mc Shane dan Glinow (2012:460) mendefinisikan budaya organisasi merupakan pola dasar dari nilai dan asumsi organisasi yang mengarahkan pegawai dalam organisasi untuk berpikir dan bertindak terhadap masalah dan kesempatan. Menurut Robbins \& Judge (2012:721), budaya organisasi memiliki 7 dimensi, yaitu: 1) Inovasi dan pengambilan resiko. Sejauh mana karyawan didukung untuk menjadi inovatif dan mengambil resiko, 2) Perhatian terhadap detail. Sejauh mana karyawan diharapkan menunjukkan kecermatan, analisis dan perhatian terhadap detail, 3) Orientasi hasil. Sejauh mana manajemen memfokus pada hasil bukannya pada teknik dan proses yang digunakan untuk mencapai hasil tersebut, 4) Orientasi orang. Sejauh mana keputusan manajemen memperhitungkan efek pada orang-orang di dalam organisasi itu, 5) Orientasi tim. Sejauh mana kegiatan kerja diorganisasikan sekitar tim-tim, ukannya individu, 6) Keagresifan. Berkaitan dengan agresivitas karyawan, 7) Kemantapan. Organisasi menekankan dipertahankannya budaya organisasi yang sudah baik.

Menurut Nimran Umar, (2011:26) sebagai indikator budaya organisasi yaitu antara lain (1) Keleluasaan kerja dalam menyelesaikan pekerjaan; (2) Toleransi organisasi terhadap pekerjaan yang beresiko; (3) Kejelasan tentang saran dan harapan atas prestasi yang ingin dicapai; (4) Upaya organisasi demi terciptanya koordinasi yang baik; (5) Dukungan atasan termasuk dalam hal komunikasi; (6) Komitmen secara keseluruhan terhadap organisasi; (7) Toleransi terhadap konflik; (8) Pola komunikasi.

\section{Kemampuan}

Kemampuan menunjukkan potensi orang untuk melaksanakan tugas atau pekerjaan. Kemampuan seseorang merupakan perwujudan dari pengetahuan dan ketrampilan yang dimiliki. Oleh sebab itu, pegawai yang memiliki kemampuan tinggi dapat menunjang tercapainya visi dan misi organisasi untuk segera maju dan berkembang pesat, guna mengantisipasi kompetisi global. Kemampuan yang dimiliki seseorang akan membuatnya berbeda dengan yang mempunyai kemampuan rata-rata atau biasa saja. Menurut Thoha (2010) kemampuan merupakan salah satu unsur dalam kematangan berkaitan dengan pengetahuan atau keterampilan yang dapat diperoleh dari pendidikan, pelatihan dan suatu pengalaman. Menurut Kaleta dalam Prasetyo, dkk. (2015:3), Kemampuan kerja merujuk suatu fitur yang kompleks dan tingkat mencerminkan interaksi antara volume kedua kegiatan fisik dan mental dan kemampuan fungsional pekerja, kesehatan mereka dan penilaian subjektif dari status mereka dalam kondisi organisasi dan sosial yang diberikan. Sulaiman (2011:112) menyatakan bahwa kemampuan adalah sifat yang dibawa lahir atau dipelajari yang memungkinkan seseorang yang dapat menyelesaikan pekerjaannya, baik secara mental ataupun fisik. Menurut Robbins (2012: 52), kemampuan kerja adalah kapasitas individu untuk melaksanakan berbagai tugas dalam pekerjaan tertentu. Dimana kemampuan individu pada hakekatnya tersusun dari dua faktor yaitu: kemampuan intelektual dan kemampuan fisik.

Menurut Zwell dalam wibowo (2011:102) mengungkapkan bahwa terdapat beberapa indikator yang dapat mempengaruhi kemampuan seseorang pegawai, yaitu 
sebagai berikut : 1) Keyakinan dan Nilai - nilai, 2) Keterampilan, 3) Pengalaman, 4)Karakteristik kepribadian, 5)Motivasi, dan 6) Isu emosional .

\section{Komitmen}

Luthans (2012:249) menyatakan bahwa komitmen organisasional adalah: Sikap yang merefleksikan loyalitas karyawan pada organisasi dan proses berkelanjutan dimana anggota organisasi mengekpresikan perhatiannya terhadap organisasi dan keberhasilan serta kemajuan yang berkelanjutan. Komitmen adalah sikap yang mencerminkan sejauh mana seorang individu mengenal dan terikat pada organisasinya. Pegawai-pegawai yang merasa lebih berkomitmen pada organisasi memiliki kebiasaan-kebiasaan yang bisa diandalkan, berusaha untuk tinggal lebih lama didalam organisasi, dan mencurahkan lebih banyak upaya dalam bekerja.

Indikator komitmen menurut Menurut (Soekidjan, 2009:67) komitmen dapat diukur melalui : a) Penerimaan terhadap tujuan organisasi, b) Keterlibatan sesuai peran dan tanggung jawab, c) Kehangatan, d) loyalitas dan rasa memiliki organisasi, e) Kesediaan untuk menampilkan usaha yang maksimal, dan f) Keinginan tetap berada dalam organisasi.

\section{Kerangka Konseptual}

Kerangka konseptual penelitian adalah suatu hubungan atau kaitan antara konsep satu terhadap konsep yang lainya dari masalah yang ingin diteliti. Kerangka konsep ini gunanya untuk menghubungkan atau menjelaskan secara panjang lebar tentang suatu topik yang akan dibahas.

Berdasarkan latar belakang serta penelitian terdahulu diatas, maka kerangka konseptual dalam penelitian ini adalah sebagai berikut:

\section{Gambar 1. Kerangka Konseptual}

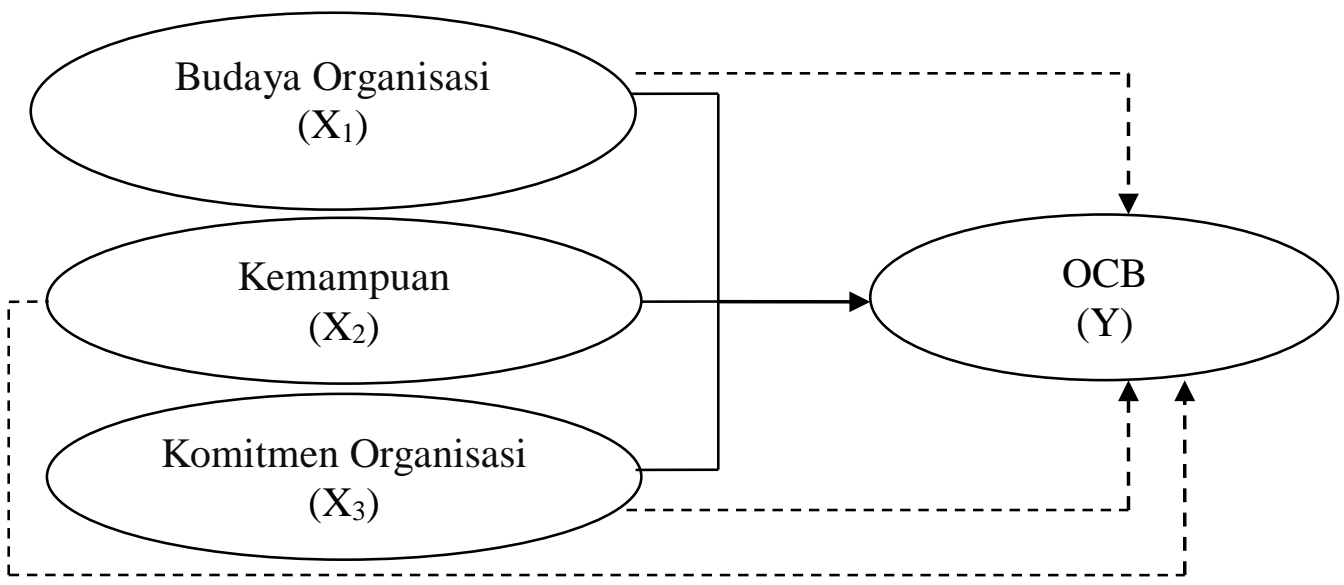

Keterangan :

- = Parsial

$=$ Simultan 


\section{Hipotesis}

Berdasarkan landasan teori dan penelitian terdahulu tersebut diatas, maka dapat disusun hipotesis sebagai berikut :

1. Terdapat pengaruh budaya organisasi, kemampuan kerja dan komitmen organisasi secara simultan terhadap organizational citizenship behavior di Bappeda Kabupaten Bojonegoro.

2. Terdapat pengaruh budaya organisasi terhadap organizational citizenship behavior di Bappeda Kabupaten Bojonegoro.

3. Terdapat pengaruh kemampuan kerja terhadap organizational citizenship behavior di Bappeda Kabupaten Bojonegoro.

4. Terdapat pengaruh komitmen organisasi terhadap organizational citizenship behavior di Bappeda Kabupaten Bojonegoro.

\section{METODE PENELITIAN \\ Jenis Penelitian}

Jenis penelitian ini explanatory research yaitu penelitian yang menjelaskan pengaruh variabel bebas terhadap variabel terikat dan kuesioner sebagai alat pengumpulan data yang pokok (Silalahi 2012:48).

\section{Pendekatan Penelitian}

Pendekatan dalam penelitian ini adalah pendekatan kuantitatif, karena penelitian ini disajikan dengan angka-angka. Penelitian kuantitatif merupakan pendekatan penelitian yang banyak dituntut menguakan angka, mulai dari pengumpulan data, penafsiran terhadap data tersebut, serta penampilan hasilnya (Arikunto, 2010:19).

\section{Indikator Variabel Penelitian}

Berdasarkan penelitian yang dilakukan didapatkan indikator dalam penelitian ini adalah sebagai berikut:

1. Menurut Nimran Umar, (2011:26) sebagai indikator budaya organisasi yaitu antara lain: a) Keleluasaan kerja dalam menyelesaikan pekerjaan, b) Toleransi organisasi terhadap pekerjaan yang beresiko, c) Kejelasan tentang saran dan harapan atas prestasi yang ingin dicapai, d) Upaya organisasi demi terciptanya koordinasi yang baik, e) Dukungan atasan termasuk dalam hal komunikasi, f) Komitmen secara keseluruhan terhadap organisasi. g) Toleransi terhadap konflik, h) Pola komunikasi.

2. Menurut Zwell dalam wibowo (2011:102) mengungkapkan bahwa terdapat beberapa indikator yang dapat mempengaruhi kemampuan seseorang pegawai, yaitu : a) Keyakinan dan Nilai - nilai, b) Keterampilan , c) Pengalaman, d) Karakteristik kepribadian, e) Motivasi, dan f) Isu emosional

3. Indikator komitmen menurut Soekidjan (2009:67) komitmen dapat diukur melalui : a) Penerimaan terhadap tujuan organisasi, b) Keterlibatan sesuai peran dan , c) tanggung jawab, d) Kehangatan, e) loyalitas dan rasa memiliki organisasi, f) Kesediaan untuk menampilkan usaha yang maksimal, dan g)Keinginan tetap berada dalam organisasi. 
4. Menurut Organ; Podsakoff; dan Mackenzie (2010) terdapat 7 (tujuh) indikator dalam organizational citizenship behavior, yaitu : a) Altruism, b) Courtesy, c) Peacemaking, d) Cheerleading , e) Conscientiousness , f)Sportsmanship dan g) Civic Virtue

\section{Lokasi Penelitian}

Penelitian ini dilaksanakan di Bappeda Kabupaten Bojonegoro yang beralamatkan di Jl. P Mas Tumapel No. 01 Bojonegoro, Kabupaten Bojonegoro, Jawa Timur 62111.

\section{Populasi, Sampel dan Teknik Pengambilan Sampel}

Populasi dalam penelitian ini adalah pegawai Bappeda Kabupaten Bojonegoro yang berjumlah 34 orang. Sampel dalam penelitian ini adalah semua pegawai Bappeda Kabupaten Bojonegoro berjumlah 34 yang selanjutnya disebut responden. Teknik pengambilan sampel yang digunakan dalam penelitian ini diambil secara total atau menggunakan metode sensus sampling sehingga keseluruhan populasi dijadikan sampel penelitian. Metode sensus sampling digunakan mengingat jumlah populasinya sedikit.

\section{Teknik Pengumpulan Data}

Data yang diperlukan dalam penelitian ini bersumber dari responden dimana data tersebut diperoleh melalui penyebaran daftar pertanyaan (angket) kepada para karyawan. Data yang digunakan dalam penelitian ini ada 2 jenis yaitu :

1. Data primer, adalah data yang dikumpulkan atau didapat secara langsung ditempat penelitian atau diperoleh langsung dan responden melalui penyebaran daftar pertanyaan.

2. Data sekunder, dimana data ini diperoleh secara tidak langsung yaitu melalaui buku-buku atau literature, dokumen dan laporan-laporan.

Data yang diperlukan dalam penelitian ini dikumpulkan melalui penyebaran untuk data pniner, sedangkan observasi dan wawancara sebagai metode pelengkap untuk mengumpulkan data skunder. Adapun metode yang digunakan secara rinci sebagai berikut:

1. Daftar pertanyaan / kuisioner, yaitu alat pengumpul data dengan menggunakan lembaran-lembaran yang telah disampaikan terdahulu kemudian disebar kepada responden yang sample penelitian.

2. Dokumentasi, yaitu alat pengumpul data dari dokumen yang sudah ada, sehingga penulis dapat memperoleh catatan-catatan yang berhubungan dengan penelitian seperti gambaran umum tempat penelitian, struktur organisasi tempat penelitian, keadaan karyawan, catatan-catatan, foto-foto dan sebagainya.

\section{Teknik Analisis Data}

Metode analisis yang digunakan dalam penelitian adalah berbentuk regresi linier berganda (multiple regression linier) dengan bantuan software SPSS. Adapun formula dari model Regresi Linier berganda tersebut adalah sebagai berikut:

$$
Y=b o+b_{1} X_{1}+b_{2} X_{2}+b_{3} X_{3}+e
$$




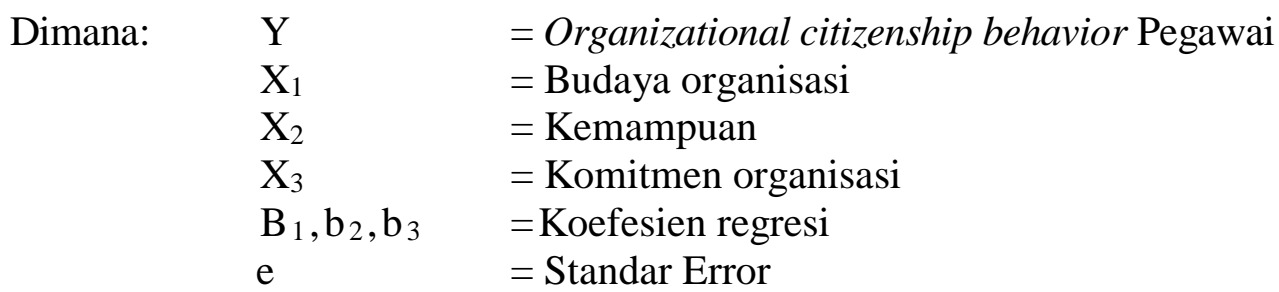

\section{HASIL PENELITIAN DAN PEMBAHASAN}

\section{Hasil Penelitian}

\section{Analisis Statistik Deskriptif}

Sebelum dilakukan pengujian hipotesis terlebih dahulu dilakukan uji statistik deskriptif. Statistik deskriptif dalam penelitian ini merujuk pada nilai rata-rata (mean) dan simpanan baku (standar deviation), nilai minimum dan maksimum serta dari seluruh variabel dalam penelitian ini yaitu Organizational Citizenship Behavior (Y), Budaya Organisasi $\left(X_{1}\right)$, Kemampuan $\left(X_{2}\right)$ dan Komitmen Organisasi $\left(X_{3}\right)$ sebagaimana ditunjukkan pada tabel dibawah ini.

Tabel 1. Descriptive Statistics

\begin{tabular}{|l|r|r|r|r|r|}
\hline & N & Minimum & Maximum & Mean & Std. Deviation \\
\hline $\begin{array}{l}\text { Budaya } \\
\text { Organisasi }\end{array}$ & 34 & 2.75 & 5.00 & 3.8406 & .55491 \\
\hline Kemampuan & 34 & 2.33 & 5.00 & 3.8091 & .68091 \\
\hline $\begin{array}{l}\text { Komitmen } \\
\text { Organisasi }\end{array}$ & 34 & 3.00 & 4.67 & 3.6324 & .44142 \\
\hline $\begin{array}{l}\text { Organizational } \\
\text { Citizenship } \\
\text { Behavior }\end{array}$ & 34 & 3.00 & 5.00 & 3.8697 & .53183 \\
\hline Valid N (listwise) & 34 & & & & \\
\hline
\end{tabular}

Sumber: Hasil Penelitian, diolah (2019)

Berdasarkan tabel diatas dapat disimpulkan bahwa Budaya Organisasi memiliki nilai mean sebesar 3.8406, Kemampuan memiliki nilai mean sebesar 3.8091, Komitmen Organisasi memiliki nilai mean sebesar 3.6324, dan Organizational Citizenship Behavior memiliki nilai mean sebesar 3.8697. Berdasarkan tabel diatas dapat disimpulkan bahwa Budaya Organisasi dalam kondisi baik, Kemampuan dalam kondisi baik, Komitmen Organisasi dalam kondisi baik, dan Organizational Citizenship Behavior dalam kondisi baik.

\section{Analisis Regresi Linier Berganda}

Dalam upaya untuk membuktikan hipotesis diperlukan analisis dengan menggunakan regresi linier berganda. Berdasarkan hasil analisis data diperoleh nilai koefisien sebagai berikut: 
Tabel 2. Hasil Analisis Regresi

\begin{tabular}{|c|c|c|c|c|c|c|}
\hline \multirow{2}{*}{\multicolumn{2}{|c|}{ Model }} & \multicolumn{2}{|c|}{$\begin{array}{c}\text { Unstandardized } \\
\text { Coefficients }\end{array}$} & \multirow{3}{*}{$\begin{array}{c}\text { Standardized } \\
\text { Coefficients } \\
\text { Beta }\end{array}$} & \multirow[b]{2}{*}{$\mathrm{t}$} & \multirow[b]{2}{*}{ Sig. } \\
\hline & & B & Std. Error & & & \\
\hline \multirow[t]{4}{*}{1} & (Constant) & .193 & .484 & & .398 & .694 \\
\hline & $\begin{array}{l}\text { Budaya } \\
\text { organisasi }\end{array}$ & .396 & .122 & .413 & 3.236 & .003 \\
\hline & Kemampuan kerja & .222 & .113 & .284 & 1.962 & .039 \\
\hline & $\begin{array}{l}\text { Komitmen } \\
\text { organisasi }\end{array}$ & .361 & .153 & .300 & 2.359 & .025 \\
\hline
\end{tabular}

Sumber: Hasil Penelitian, diolah (2019)

Dari hasil analisis data yang terdapat dalam lampiran dan dirangkum pada tabel diatas, diketahui bahwa persamaan regresi untuk hasil penelitian ini adalah sebagai berikut :

$$
\mathrm{Y}=0.193+0.396 \mathrm{X}_{1}+0.222 \mathrm{X}_{2}+0.361 \mathrm{X}_{3}+\mathrm{e}
$$

Persamaan diatas mengandung maksud bahwa organizational citizenship behavior dipengaruhi oleh Budaya organisasi, kemampuan kerja dan komitmen organisasi. Persamaan diatas dapat di jabarkan sebagai berikut :

Konstanta $=0.193$ artinya bahwa apabila tidak ada variabel Budaya organisasi, kemampuan kerja, komitmen organisasi, maka tingkat organizational citizenship behavior adalah sebesar 0.193 satuan serta Koefisien Budaya organisasi sebesar 0.396 artinya bahwa apabila Budaya organisasinaik satu satuan, maka organizational citizenship behavior Bappeda Kabupaten Bojonegoro akan meningkat sebesar 0.396 satuan. Pada koefisien kemampuan kerja sebesar 0.222 artinya bahwa apabila kemampuan kerja naik satu satuan, maka organizational citizenship behavior Bappeda Kabupaten Bojonegoro akan meningkat sebesar 0.222 satuan dan untuk Koefisien komitmen organisasi sebesar 0.361 artinya bahwa apabila komitmen organisasi naik satu satuan, maka organizational citizenship behavior Bappeda Kabupaten Bojonegoro akan meningkat sebesar 0.361 satuan.

\section{Pengaruh Budaya Organisasi, Kemampuan Kerja, Komitmen Organisasi Secara Simultan Terhadap Organizational Citizenship Behavior}

Pengujian hipotesis pertama yang menyatakan bahwa secara simultan pengaruh Budaya organisasi, kemampuan kerja, komitmen organisasi mempunyai pengaruh signifikan terhadap organizational citizenship behavior Pegawai Bappeda Kabupaten Bojonegoro digunakan analisis uji $\mathrm{F}$ (Anova) sebagaimana dapat dilihat pada tabel berikut :

Tabel 3. Hasil Analisis Uji F (Anova)

\begin{tabular}{|c|l|r|r|r|r|c|}
\hline \multicolumn{2}{|c|}{ Model } & Sum of Squares & df & $\begin{array}{c}\text { Mean } \\
\text { Square }\end{array}$ & F & Sig. \\
\hline \multirow{2}{*}{1} & Regression & 6.550 & 3 & 2.183 & 23.525 & $.000^{\mathrm{a}}$ \\
\cline { 2 - 7 } & Residual & 2.784 & 30 & .093 & & \\
\cline { 2 - 7 } & Total & 9.334 & 33 & & & \\
\hline
\end{tabular}

Sumber: Hasil Penelitian, diolah (2019) 
Berdasarkan hasil analisis data dengan menggunakan uji $\mathrm{F}$ diperoleh nilai $\mathrm{F}$ hitung sebesar 23.525 dengan tingkat signifikansi sebesar 0.000 (lebih kecil dari 0,05) yang berarti bahwa secara simultan Budaya organisasi, kemampuan kerja komitmen organisasi mempunyai pengaruh signifikan terhadap organizational citizenship behavior Pegawai Bappeda Kabupaten Bojonegoro. Dengan demikian dapat dikatakan bahwa hipotesis yang menyatakan bahwa secara simultan ada pengaruh signifikan Budaya organisasi, kemampuan kerja komitmen organisasi pegawai terhadap organizational citizenship behavior Pegawai Bappeda Kabupaten Bojonegoro diterima.

Selanjutnya untuk mengetahui tingkat besarnya pengaruh Budaya organisasi, komitmen organisasi, kemampuan kerja terhadap organizational citizenship behavior pegawai Bappeda Kabupaten Bojonegoro digunakan analisis koefisien determinasi. Untuk lebih jelasnya dapat dilihat pada tabel berikut:

Tabel 4. Hasil Analisis Koefisien Determinasi

\begin{tabular}{|l|r|r|r|r|}
\hline Model & $\mathrm{R}$ & $\begin{array}{c}\mathrm{R} \\
\text { Square }\end{array}$ & $\begin{array}{c}\text { Adjusted R } \\
\text { Square }\end{array}$ & $\begin{array}{c}\text { Std. Error of } \\
\text { the Estimate }\end{array}$ \\
\hline 1 & $.838^{\mathrm{a}}$ & .702 & .672 & .30464 \\
\hline
\end{tabular}

Sumber: Hasil Penelitian, diolah (2019)

Hasil analisis menunjukkan bahwa nilai koefisien determinasi sebesar $\mathrm{R}^{2}=0.702$ yang berarti bahwa $70.2 \%$ organizational citizenship behavior dapat dijelaskan oleh semangat kerja, komitmen organisasi, kemampuan kerja, sedangkan sisanya sebesar $29.8 \%$ di pengaruhi oleh variabel lain diluar Budaya organisasi, komitmen organisasi, kemampuan kerja.

\section{Pengaruh Budaya Organisasi, Kemampuan Kerja, Komitmen Organisasi Secara Parsial Terhadap Organizational Citizenship Behavior}

Berdasarkan hasil analisis data diperoleh bahwa nilai t pada masing-masing variabel yang dapat dilihat pada tabel sebagai berikut :

Tabel 5. Tabel Analisis Uji-t

\begin{tabular}{|l|l|r|r|}
\hline \multicolumn{2}{|l|}{ Model } & $\mathrm{t}$ & \multicolumn{1}{c|}{ Sig. } \\
\hline \multirow{3}{*}{1} & (Constant) & .398 & .694 \\
\cline { 2 - 4 } & Budaya organisasi & 3.236 & .003 \\
\cline { 2 - 4 } & Kemampuan kerja & 1.962 & .039 \\
\cline { 2 - 4 } & Komitmen organisasi & 2.359 & .025 \\
\hline
\end{tabular}

Sumber: Hasil Penelitian, diolah (2019)

Berdasarkan tabel tersebut diatas dapat dijelaskan pengujian hipotesisnya sebagai berikut :

1. Nilai t hitung Budaya organisasi adalah sebesar 3.236 dengan signifikansi sebesar 0.003 (lebih kecil dari 0,05) artinya bahwa secara parsial Budaya organisasi mempunyai pengaruh signifikan terhadap organizational citizenship behavior.

2. Nilai t hitung kemampuan kerja adalah sebesar 1.962 dengan signifikansi sebesar 0.039 (lebih kecil dari 0,05) artinya bahwa secara parsial kemampuan kerja mempunyai pengaruh signifikan terhadap organizational citizenship behavior. 
3. Nilai t hitung komitmen organisasi adalah sebesar 2.359 dengan signifikansi sebesar 0.025 (lebih kecil dari 0,05) artinya bahwa secara parsial komitmen organisasi mempunyai pengaruh signifikan terhadap organizational citizenship behavior

Berdasarkan hasil analisis data diketahui, Budaya organisasi, kemampuan kerjadan komitmen organisasi mempunyai pengaruh yang signifikan terhadap organizational citizenship behavior. Dengan demikian dapat dikatakan bahwa hipotesis yang menyatakan ada pengaruh signifikan Budaya organisasi, kemampuan kerja dan komitmen organisasi secara parsial terhadap organizational citizenship behavior Pegawai Bappeda Kabupaten Bojonegoro diterima.

\section{Pembahasan}

Berdasarkan hasil analisis data Statistik deskriptif yang dilakukan sebelumnya didapatkan Budaya Organisasi memiliki nilai mean sebesar 3.8406, Kemampuan memiliki nilai mean sebesar 3.8091, Komitmen Organisasi memiliki nilai mean sebesar 3.6324, dan Organizational Citizenship Behavior memiliki nilai mean sebesar 3.8697. oleh karena itu dapat disimpulkan bahwa Budaya Organisasi, Kemampuan, Komitmen Organisasi dan Organizational Citizenship Behavior dalam kondisi baik

Berdasarkan hasil analisis data dapat diketahui pengaruh Budaya Organisasi, Kemampuan Kerja dan Komitmen Organisasi secara simultan terhadap Organizational Citizenship Behavior di Bappeda Kabupaten Bojonegoro diperoleh nilai $\mathrm{F}$ hitung sebesar 23.525 dengan tingkat signifikansi sebesar 0.000 (lebih kecil dari 0,05) yang berarti bahwa secara simultan Budaya Organisasi, Kemampuan Kerja dan Komitmen Organisasi mempunyai pengaruh signifikan terhadap Organizational Citizenship Behavior Bappeda Kabupaten Bojonegoro. Dengan demikian dapat dikatakan bahwa apabila terjadi perubahan pada Budaya Organisasi, Kemampuan Kerja, dan Komitmen Organisasi secara simultan maka akan berpengaruh signifikan terhadap peningkatan dan penurunan Organizational Citizenship Behavior di Bappeda Kabupaten Bojonegoro. Dari hasil analisis data juga dapat diketahui sebesar $70.2 \%$ Organizational Citizenship Behavior di Bappeda Kabupaten Bojonegoro dapat dipengaruhi oleh variabel Budaya Organisasi, Komitmen Organisasi dan Kemampuan Kerja, sedangkan sisanya sebesar $29.8 \%$ dipengaruhi oleh variabel lain diluar Budaya Organisasi, Komitmen Organisasi, Kemampuan Kerja.

Berdasarkan hasil analisis data tersebut diatas dapat diketahui pengaruh Budaya Organisasi Terhadap Organizational Citizenship Behavior di Bappeda Kabupaten Bojonegoro yang diperoleh nilai t hitung Budaya organisasi adalah sebesar 3.236 dengan signifikansi sebesar 0.003 (lebih kecil dari 0,05) artinya bahwa secara parsial Budaya organisasi mempunyai pengaruh signifikan terhadap organizational citizenship behavior di Bappeda Kabupaten Bojonegoro. Dengan demikian dapat dikatakan bahwa apabila terjadi perubahan pada Budaya Organisasi maka akan berpengaruh signifikan terhadap peningkatan dan penurunan Organizational Citizenship Behavior di Bappeda Kabupaten Bojonegoro. Hasil penelitian ini mendukung hail penelitian yang dilakukan oleh Husodo (2018), dimana Hasil penelitian menunjukan bahwa budaya organisasi berpengaruh terhadap Organizational Citizenship Behavior,

Berdasarkan hasil analisis data tersebut diatas dapat diketahui pengaruh Kemampuan Kerja Terhadap Organizational Citizenship Behavior di Bappeda 
Kabupaten Bojonegoro yang diperoleh nilai t hitung kemampuan kerja adalah sebesar 1.962 dengan signifikansi sebesar 0.039 (lebih kecil dari 0,05) artinya bahwa secara parsial kemampuan kerja mempunyai pengaruh signifikan terhadap organizational citizenship behavior di Bappeda Kabupaten Bojonegoro. Dengan demikian dapat dikatakan bahwa apabila terjadi perubahan pada Kemampuan Kerja pegawai maka akan berpengaruh signifikan terhadap peningkatan dan penurunan Organizational Citizenship Behavior di Bappeda Kabupaten Bojonegoro. Hasil penelitian ini mendukung penelitian Nugraha dan Adnyani (2018), dimana dalam asil analisisnya menunjukkan pengaruh secara parsial komitmen organiasi terhadap OCB pada Sekretariat Daerah Kota Denpasaradalah positif dan signifikan. Artinya, semakin baik komitmen organisasi, maka semakin tinggi OCB dari pegawai honor pada Sekretariat Daerah Kota Denpasar.

Berdasarkan hasil analisis data tersebut diatas dapat diketahui pengaruh Komitmen Organisasi Terhadap Organizational Citizenship Behavior di Bappeda Kabupaten Bojonegoro yang diperoleh nilai t hitung komitmen organisasi adalah sebesar 2.359 dengan signifikansi sebesar 0.025 (lebih kecil dari 0,05) artinya bahwa secara parsial komitmen organisasi mempunyai pengaruh signifikan terhadap organizational citizenship behaviorr di Bappeda Kabupaten Bojonegoro. Dengan demikian dapat dikatakan bahwa apabila terjadi peningkatan atau penurunan pada Komitmen Organisasi pegawai maka akan berpengaruh signifikan terhadap peningkatan dan penurunan Organizational Citizenship Behavior di Bappeda Kabupaten Bojonegoro. Hasil penelitian ini mendukung Penelitian yang dilakukan oleh Rahayu (2017) dimana hasil analisis menunjukkan bahwa variabel komitmen organisasi berpengaruh signifikan terhadap variabel organizational citizenship behavior, dengan koefisien beta sebesar 0,539 atau 53,9\% (signifikansi 0,000).

\section{KESIMPULAN DAN SARAN \\ Kesimpulan}

Berdasarkan hasil analisis data dan pembahasan, maka dapat ditarik kesimpulan sebagai berikut :

1. Budaya Organisasi, Kemampuan Kerja, Komitmen Organisasi dan Organizational Citizenship Behavior di Bappeda Kab. Bojonegoro semuanya dlaam kondis baik.

2. Budaya Organisasi, Kemampuan Kerja, dan Komitmen Organisasi secara simultan memiliki pengaruh yang signifikan terhadap Organizational Citizenship Behavior di Bappeda Kab. Bojonegoro.

3. Budaya Organisasi memiliki pengaruh yang signifikan terhadap Organizational Citizenship Behavior di Bappeda Kab. Bojonegoro.

4. Kemampuan Kerja memiliki pengaruh yang signifikan terhadap Organizational Citizenship Behavior di Bappeda Kab. Bojonegoro.

5. Komitmen Organisasi memiliki pengaruh yang signifikan terhadap Organizational Citizenship Behavior di Bappeda Kab. Bojonegoro. 


\section{Saran}

Berdasarkan kesimpulan tersebut diatas, maka penulis dapat memberikan saran sebagai berikut :

1. Pada penelitian selanjutnya dapat dicarai variabel lain selain variabel dalam penelitian ini karena masih ada sebesar 54\% Organizational Citizenship Behavior Bappeda Kabupaten Bojonegoro yang dapat dipengaruhi oleh variabel lain diluar Budaya Organisasi, Komitmen Organisasi, Kemampuan Kerja

2. Budaya Organisasi perlu untuk ditingkatkan karena juga mempunyai pengaruh yang signifikan terhadap Organizational Citizenship Behavior Bappeda Kabupaten Bojonegoro. Bahkan pengaruhnya paling dominan dari pada variabel kemampuan kerja dan komitmen organisasi.

3. Setelah melakukan peningkatan pada variabel budaya organisasi, komitmen organisasi di Bappeda Kabupaten Bojonegoro juga perlu untuk ditingkatkan Karena juga mempunyai pengaruh yang signifikan terhadap Organizational Citizenship Behavior meskipun pengaruhnya tidak sebesar budaya organisasi.

\section{DAFTAR PUSTAKA}

Alias Masek \& Sulaiman Yamin. 2011. The Effect of Problem Based Learning on Critical Thingking Ability: A Theoretical and Empirical Review. Journal of International Review of Social Sciences and Humanities, Vol.2 (1), hlm. 215221.

Arikunto, S. 2010. Prosedur Penelitian Suatu Pendekatan Praktik. Jakarta: Rineka Cipta.

Asra, Abuzar dan Prasetyo, Achmad, 2015. Pengambilan Sampel dalam Penelitian Survei. Jakarta: Rajawali Pers.

Luthans, Fred. 2012. Perilaku Organisasi. Yogyakarta: Penerbit Andi.

McShane \& Von Glinow 2012. Organizational Behaviour: Emerging Knowledge Global Realit.

Nimran Umar, 2011. Perilaku Organisasi, Cetakan Ketiga, CV. Citra Media, Surabaya.

Novliadi, P. 2010. Intensi Turnover Karyawan Ditinjau dari Budaya Perusahaan dan Kepuasan Kerja. Makalah : Fakultas Kedokteran, Jurusan Psikologi USU.

Organ, D. W., P. M. Podsakoff, S. B. MacKenzie. 2010. Organizational Citizenship Behavior: Its Nature, Antecedents, and Consequences. USA: Sage Publications, Inc.

Robbins, P. Stephen dan Timothy A. Judge. 2012. Perilaku Organisasi. Jakarta: Salemba Empat.

Silalahi, Ulber. 2012. Metode Penelitian Sosial. Bandung: Refika Aditama.

Soekidjan. 2009. Manjaemen Sumber Daya Manusia. Jakarta: BumiAksara

Sumarni, Murti dan John Soeprihanto. 2010. Pengantar Bisnis (Dasar-dasar Ekonomi Perusahaan). Edisi ke 5. Yogyakarta: Liberty Yogyakrta

Thoha, Miftah, 2010. Kepemimpinan dalam Manajemen, Jakarta : Rajawali Pers.

Wibowo. 2011. Manajemen Kinerja. Jakarta: Rajawali Pers. 